\title{
Sealant Dosage Form
}

National Cancer Institute

\section{Source}

National Cancer Institute. Sealant Dosage Form. NCI Thesaurus. Code C149892.

Liquid, more or less viscous, sterile preparation intended for use as tissue glue. 